\title{
Revisiting the Catalogue Cards in University Libraries in Nigeria
}

\author{
Obiozor-Ekeze Roseline Nkechi \\ Nnamdi Azikiwe University Library, Awka, Nigeria \\ Email: roseobiozor70@gmail.com
}

Received 24 October 2014; accepted 23 March 2015; published 26 March 2015

Copyright (c) 2015 by author and Scientific Research Publishing Inc.

This work is licensed under the Creative Commons Attribution International License (CC BY). http://creativecommons.org/licenses/by/4.0/

(c) (i) Open Access

\begin{abstract}
The card catalogues are neglected in the university libraries in Nigeria because of the introduction of OPAC (Online Public Access Catalogue) which is rarely seen in most of university libraries. After conducting a research on the usefulness of card catalogues, the researcher observes that users of the libraries still appreciate the card catalogues in the libraries because they help them to know the collections of the library.
\end{abstract}

Keywords

Books, Card Catalogues, University Libraries, Department of Science Education, Nigeria

\section{Introduction}

The catalogue cards have being the longest catalogue in use in universities. Reitz (2004) defines card catalogues as a list of the holdings of a library, printed, typed or handwritten on catalogue cards, with each representing a single bibliographic item in the collection. The catalogue informs the users of the library on what a library has, being in the traditional library or virtual library. The catalogue cards inform the users of the library on where to get their materials without much wasting time. Agwolu (2003) points out that "the academic health, intellectual vitality and effectiveness of any university depend largely upon the state of the library". It is the library catalogues that make the library to be an organized place in the university. OCLC (online computer library catalogue) also comments that library catalogues manage description and access for mostly published tangible materials such as books, serials and audiovisual media plus licensed materials such as abstracting and indexing services. The library catalogues have long supported the mission of the libraries which is to provide information resources for teaching, studying and research.

The catalogue cards are still very useful tools for the users of the libraries and in particular for those of us that are living in the developing countries where libraries are under-funded. Taylor \& Joudrey (2009) report that cata- 
logue cards are still found in libraries throughout the world where electricity is not always reliably presented or smaller libraries which cannot afford the software and equipment necessary to switch to an online catalog. They further explain that catalogue cards are still in use in United States of America for specific parts of the collection, older materials or special collections.

The card catalogues are in deplorable condition in Nigerian universities libraries. Since Internet came into existence in Nigeria, librarians have talked about Internet resources. They are no longer interested in producing catalogue cards for the users of their library. Nobody cares about the card catalogues' production and maintenance. Online Public Access Catalogue (OPAC) is the dream of every library. It is good for libraries that can afford them. Only very few universities in Nigeria can boost functional automate libraries. Hsieh-Yee (2000) and Zhang (2000) report that once an Internet resource is catalogued, it becomes a virtual part of the library's collection and can be accessed only through the OPAC. The neglect in the card catalogue makes the users of libraries to walk straight to the shelves to look for their materials instead of consulting the card catalogues first, thereby scattering the shelves and tearing some books.

There have not been studies again on the usefulness of card catalogues in university libraries in Nigeria since the introduction of OPAC in the libraries. Librarians are presenting papers in conferences about the new technologies in the libraries in the developed countries without thinking of the possibilities here. Production of card catalogues is neglected in the university libraries in Nigeria. Books are catalogued and classified, and then taken to the shelves without their cards being produced. This makes the card catalogues not to be projecting their roles any longer in the library. Since there is a lack of empirical studies in this regard in Nigeria, it is therefore wise to conduct this study to fill the gap.

\subsection{Statement of Problems}

Card catalogues are now seen as something that should not be seen again in university libraries. In conferences and workshops, librarians talk about Online Public Access Catalogue (OPAC). Nobody wants to talk about how to maintain the traditional card catalogues, which have existed long in the libraries. No university in the southeast has OPAC, yet their card catalogues are in a mess. It is a fact that Online Public Access Catalogue has radically changed the way users access the catalogue (Coyle \& Hillmann, 2007). But universities in the developing countries should maintain their card catalogues even if OPAC is acquired.

\subsection{Purpose of Study}

The purpose of this study is to identify the need for catalogue cards in university libraries and why it should be put in order again. Specifically, the work intends to:

1) Find out if card catalogues still exist in university libraries;

2) Find out if users still consult these card catalogues.

\subsection{Scope of the Study}

The study was geographically limited to university libraries in southeast of Nigeria. The content was delimited to investigating why production and maintenance of card catalogues were neglected in university libraries.

\subsection{Research Questions}

1) Are the card catalogues still functional in your university library?

2) Are users still consulting the card catalogues in your university library?

\subsection{Questionnaire}

\section{For users}

Are the card catalogues still functional in your university library?

1) Do you consult the card catalogues regularly?

2) Are new cards being filled?

3) Are the cards properly arranged?

4) Are the catalogue cards still useful to use? 
Questions the librarians answered orally

5) Are your card catalogues still functional?

6) How often do you type and fill new cards in the boxes?

7) Do you still card and retype born cards?

8) What do you think of the condition of catalogue cards in your university library?

\section{Methodology}

\subsection{Research Design}

The study was a descriptive survey.

\subsection{Population of the Study}

Data was collected from ten (10) universities in south east Nigeria-UNN, Nsukka, NAU, Awka, Federal University of Technology, Enugu, Imo State University, Uturu, Anambra State University, Uli, Madonna University Okija and Tansi Oba. The population used for the study were staff of Department of Science Education that are registered in the library, fourth year students from department of science education that are registered in the library and only librarians in cataloguing and classification section of the university libraries.

The breakdown of the population is shown in Table 1.

\subsection{Sample and Sampling Technique}

Purposive sampling was used to determine the population. There are more females students from the department that use the library. Their ages ranges between 18 and 26 years. The lecturers that were used were mainly the younger lecturers who were constant in the library.

\subsection{Instrument for Data Collection}

A questionnaire was constructed for the collection of data. The questions were in six items made for users of the university libraries alone. See the appendix. Librarians in cataloguing and classification sections were asked questions orally so as to get the actual conditions of the card catalogues. Two hundred and ninety-nine (299) were the respondents. These are the ones that still consult the card catalogues when they visit the university library (Table 2).

\section{Findings}

It was gathered that the catalogue are not functional. New cards are not being typed and filled. Students and staff are still willing to use the card catalogue. $65 \%$ of the users confirm that the card catalogue is a very useful tool. It gives new information on what is new in the library.

Table 1. The breakdown of the population is shown in the table below.

\begin{tabular}{cccccc}
\hline Universities & $\begin{array}{c}\text { Total No. of Reg. Staff } \\
\text { in Science Education }\end{array}$ & $\begin{array}{c}\text { Total No. of Librarian in } \\
\text { Cataloguing and Classification }\end{array}$ & $\begin{array}{c}\text { 400 Level Students of } \\
\text { Science Education }\end{array}$ & $\begin{array}{c}\text { Total } \\
\text { Percentage } \\
(\%)\end{array}$ \\
\hline UNN & 20 & 10 & 35 & 65 & 15.8 \\
NAU, Awka & 15 & 2 & 30 & 47 & 11.4 \\
Futo, Owerri & 12 & 3 & 25 & 40 & 9.7 \\
ESUT, Enugu & 10 & 2 & 31 & 43 & 10.4 \\
IMSU, Owerri & 15 & 3 & 33 & 51 & 12.4 \\
EBSU, Abakaliki & 10 & 2 & 25 & 37 & 9 \\
ABSU, Uturu & 13 & 3 & 25 & 44 & 10.7 \\
ANSU Uli & 10 & 2 & 32 & 37 & 9 \\
Madona, Okija & 13 & 2 & 30 & 47 & 11.4 \\
Tansi, Oba & 10 & 2 & 294 & 42 & 10.2 \\
Total & 128 & 31 & & 453 \\
\hline
\end{tabular}


Table 2. The number of reg. users (staff and 400 level students) of science education department who still consult the card catalogues.

\begin{tabular}{ccccc}
\hline Universities & Reg. Staff & 400 Level Reg. Students & Total & $\%$ \\
UNN & 15 & 28 & 43 & 14.38 \\
NAU, Awka & 10 & 20 & 30 & 10.03 \\
Futo, Owerri & 10 & 18 & 28 & 10.7 \\
ESUT, Enugu & 8 & 21 & 29 & 9.69 \\
IMSU, Owerri & 9 & 24 & 33 & 11.03 \\
EBSU, Abakaliki & 7 & 15 & 22 & 7.35 \\
ABSU, Uturu & 9 & 17 & 26 & 8.69 \\
ANSU, Uli & 6 & 15 & 21 & 7.70 \\
Madona, Okija & 10 & 25 & 35 & 11.70 \\
Tansi, Oba & 10 & 22 & 32 & 10.70 \\
Total & 94 & 205 & 299 &
\end{tabular}

Librarians who were asked questions orally confirm the poor state $\mathrm{s}$ of the catalogue cards. They confirmed that the library materials are catalogue and classified but no typists to type the cards. They reported that the university library management wants the library to be an automated library.

\section{Conclusion}

There is a need to revisit the card catalogues again in our university libraries, even if the library has introduced OPAC. Most of the Universities in Nigeria have not started using the OPAC. Even those that are using them have one problem or the other. University libraries still buy books whose original cataloguing is done directly in the libraries. So, there is no reason that librarians in Nigerian university libraries should not be producing and maintaining card catalogues if in the developing countries university libraries still maintain their card catalogues.

\section{References}

Agwolu, C.C. (2003). Libraries and Information Management in Nigeria. Maduguri: Ed-Inform Services.

Coyle, K., \& Hillmann, D. (2007). Resource Description and Access (RDA): Cataloguing Rules for the 20th Century. D-Lib, 13. http://dx.doi.org/10.1045/january2007-coyle

Hsieh-Yee, I. (2000). OCLC Systems and Services. 16, 1-10.

Reitz, J. M. (2004). Dictionary for Library and Information Science. London: Libraries Unlimited.

Taylor, A. G., \& Joudrey, D. N. (2009). The Organization of Information Westport. Conn.: Libraries Unlimited (Library and Information Science Text Series).

Zhancy, A. (2000). Cataloguing Internet Resources Using the Voyager System OCLC Systems and Services. 16, $107-113$. 